\title{
SUBGRADE STRENGTHENING OF ROADS ON BLACK COTTON SOIL USING QUARRY DUST
}

\author{
B.R.K. Sai Ganesh Kumar', R.V.L. Sai Sumedha ${ }^{2}$, U. Pradeep ${ }^{3}$, K. Gowtham Kumar ${ }^{4}$, \\ P. Padmanabha Reddy ${ }^{5}$

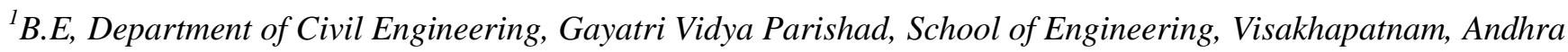 \\ Pradesh, India \\ ${ }^{2}$ B.E, Department of Civil Engineering, Gayatri Vidya Parishad, School of Engineering, Visakhapatnam, Andhra \\ Pradesh, India \\ ${ }^{3}$ B.E, Department of Civil Engineering, Gayatri Vidya Parishad, School of Engineering, Visakhapatnam, Andhra \\ Pradesh, India \\ ${ }^{4}$ Assistant Professor, Department of Civil Engineering, Gayatri Vidya Parishad, School of Engineering, \\ Visakhapatnam, Andhra Pradesh, India \\ ${ }^{5}$ Assistant Professor, Department of Civil Engineering, Gayatri Vidya Parishad, School of Engineering, \\ Visakhapatnam, Andhra Pradesh, India
}

\begin{abstract}
Black cotton soil is a highly clayey soil it has very low bearing capacity and high shrinkage and swelling characteristics. Due to its peculiar characteristics, it forms a very poor foundation material for road construction and due to very low CBR values of black cotton soil; excessive pavement thickness is required for designing flexible pavement. Ground improvement technique such as soil stabilization and reinforcement are employed to improve the mechanical behavior of soil thereby enhancing the reliability of construction. The wide spread of black cotton soil in various places in India posses problems to the construction activities, especially sub grade problems. The quarry dust a by-product from the crushing process during quarrying activities is one of the waste products. This by product is left in the neighborhood of the quarry causing environmental pollution and serious health hazards. Quarry dust consists mainly of excess fines and it exhibits high shear strength which is highly beneficial for its use as a geotechnical material. Hence an experimental study is undertaken to check the suitability of quarry dust as a stabilizer to improve the engineering properties of black cotton soil. Black cotton soil sample which is used for the study is taken from an area called Bhimavaram which is located in East Godavari district of Andhra Pradesh state in India. The quarry dust sample which is used in improving the black cotton soil characteristics is taken from Tekkali Srikakulam district located in Andhra Pradesh state, India.
\end{abstract}

An attempt is being done to stabilize the black cotton soil by adding quarry dust in percentages of 10\%, 20\%, 30\%, 40\%. The test values of CBR test, swell test are compared for different percentages of quarry dust with black cotton soil values

Keywords: Black cotton soil, Quarry dust, stabilization, CBR, swell

\section{INTRODUCTION}

In ancient times there was nothing more than a sparse network of tracks for humans to use in order to reach the feeding and drinking places. These tracks differed only slightly from the tracks made by any other mammal for the same purpose, except that obstacles e.g. boulders, were removed from the more important routes and thorn bushes trimmed back by humans. More elaborate lines of communication than these simple tracks did not appear until the increasing number of people in certain areas and the social structure and organization of communities demanded more permanent contact between communities. Roads thus appeared when groups of people started to interact with each other by travelling, doing business, fighting, etc. This occurred around $3500 \mathrm{BC}$ with the invention of the wheel and development of chariots and wagons.

\section{LITERATURE SURVEY}

Ken c et al(1) studied on the geophysical use of quarry dust as admixture to soil stabilization and modification. The introduction of quarry dust improves the engineering behaviors of the soil. There is a improvement in the CBR value of the soil by addition of quarry dust, higher CBR values enhances their potential for use as a sub base for flexible pavement. When quarry dust is added with expansive soil it is expected that it will more porous, less durable, reduce cohesion etc. It also causes a gain in strength due to better interlocking

Ms. Arpitha and V.Patel (2) conducted a study on geotechnical properties of black cotton soil contaminated by castor oil and its stabilization by sawdust. California bearing ratio of black cotton soil with $5 \%, 10 \%$ and $15 \%$ castor oil as contaminant and the effect of saw dust as stabilizer on black 
cotton soil is observed. The unconfined compressive strength of stabilized soil increases as the time duration increases .The maximum CBR value of stabilized soil was found with $10 \%$ saw dust.

RamaSusheel kumar, J.Vikranth (3) studied on the application of fly ash and coconut coir for the subgrade strengthening. Various types of materials used in this study are Black cotton soil, fly ash, coconut coir. To perform this analysis California bearing ratio test and unconfined compressive strength test are conducted using the required equipment. The results of black cotton soil are compared with different percentages of coconut coir and fly ash from the comparison it is concluded that with the addition of $20 \%$ flyash and $1 \%$ of coconut coir the C.B.R value is increased by $83 \%$, with the addition of $20 \%$ of fly ash and $1 \%$ of coconut coir the U.C.S value is increased by $120 \%$.

D.K.Abubakar et al(4) studied on the stabilization of black cotton soil using ground nut shell ash. The moisture density relationship follows a trend of increasing optimum moisture content and decreasing maximum dry density at the standard proctor compaction. The CBR and UCS values also improved so the groundnut shell ash could be used as a stabilizer. The values of liquid limit, plastic limit are also increased.

\section{MATERIALS USED}

\subsection{Properties of Black Cotton Soil}

The soil formed in Deccan India with the disintegration of black lava. In India, expansive soils are called as Black Cotton soil. The name "Back Cotton" as an agricultural origin. Most of these soils are black in colour and are good for growing Cotton. All the black soils are not expansive soils and all the expansive soils are not black in colour. These soils passed high strength in summer and decreased rapidly in winter. The soil has a swelling property due to the presence of montmorillonite mineral.The swelling soils of India have their origin in subaqueous decomposition of basalt rocks or weathering In-Situ. It is very necessary to discuss about the Engineering behaviour of soils. From this information civil structures can be prevented from the damages causing Expansive soils. Black soils are highly argillaceous and are relatively rich in $\mathrm{CocO}_{3}$.

Table 1: Physical and Engineering Properties of Black cotton soil

\begin{tabular}{|l|l|l|}
\hline S.No & Description & Value \\
\hline 1 & Soil grain distribution & \\
\hline \multirow{5}{*}{} & Gravel (>4.75mm) (\%) & 0 \\
\cline { 2 - 3 } & Sand (4.75-0.0 75mm) $(\%)$ & 38.5 \\
\cline { 2 - 3 } & Fines (<0.075mm) (\%) & 61.5 \\
\hline \multirow{5}{*}{} & Atterberg's limits & \\
\cline { 2 - 3 } & Liquid Limit (\%) & 54 \\
\cline { 2 - 3 } & Plastic Limit (\%) & 20 \\
\cline { 2 - 3 } & Shrinkage limit (\%) & 15 \\
\hline 4 & IS-Classification & $\mathrm{CH}$ \\
\hline 4 & Specific gravity & 1.8 \\
\hline
\end{tabular}

\begin{tabular}{|c|c|c|}
\hline \multirow[t]{3}{*}{5} & Compaction Properties & \\
\hline & $\begin{array}{ll}\text { Optimum } & \text { Moisture } \\
\text { Content }(\%) & \end{array}$ & 19 \\
\hline & $\begin{array}{l}\text { Maximum Dry Density } \\
(\mathrm{g} / \mathrm{cc})\end{array}$ & 1.47 \\
\hline \multirow[t]{2}{*}{6} & Swell characteristics & 138 \\
\hline & Free swell index $(\%)$ & High \\
\hline
\end{tabular}

\subsection{Properties of Quarry Dust}

The quarry dust is the by-product which is formed in the processing of the granite stones which broken downs into the coarse aggregates of different sizes.

The Quarry Dust used for this study is collected from Tekkali in Srikakulam District. , Andhra Pradesh, India. Advantages of Quarry Dust: The Specific gravity depends on the nature of the rock from which it is processed and the variation is less.

Disadvantages of Quarry Dust: Shrinkage is more in when compared to that of the natural river sand. Water absorption is present so that increase the water addition to the dry mix

Table 2: Properties of quarry dust

\begin{tabular}{|l|l|l|}
\hline S.No & Description & Value \\
\hline 1 & Specific Gravity & 2.43 \\
\hline 2 & Liquid limit (\%) & Non plastic \\
\hline 3 & Plastic limit (\%) & Non plastic \\
\hline 4 & Compaction Properties & \\
\cline { 2 - 3 } & $\begin{array}{l}\text { proctors maximum dry } \\
\text { density (t/cu.m) }\end{array}$ & 2.24 \\
\cline { 2 - 3 } & $\begin{array}{l}\text { Optimum moisture } \\
\text { content(\%) }\end{array}$ & 18.5 \\
\hline 5 & Colour & Grey \\
\hline
\end{tabular}

\section{EXPERIMENTAL PROGRAM}

A series of C.B.R. and swell test on black cotton soil with quarry dust are carried out. The test results are listed below

Table 3: C.B.R. results of Black cotton soil with different combinations of Quarry dust.

\begin{tabular}{|l|l|l|l|l|l|}
\hline Quarry dust $\%$ & 0 & 10 & 20 & 30 & 40 \\
\hline CBR & 6.72 & 7.12 & 11.94 & 12.02 & 12.6 \\
\hline
\end{tabular}

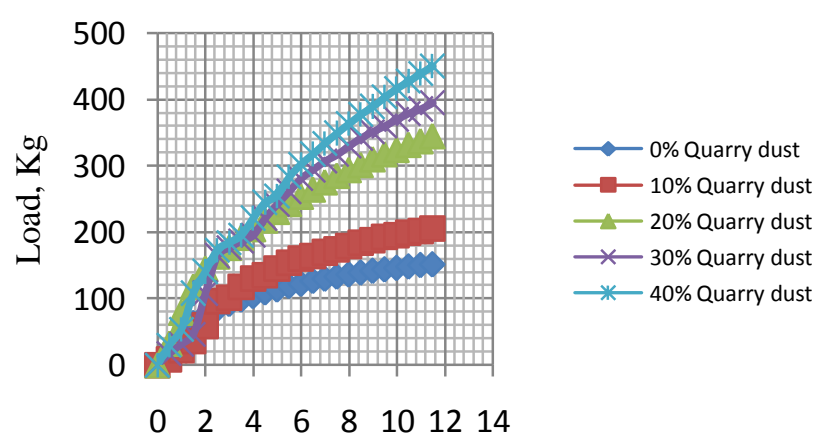

Pentration ,mm 
Table 4: swells pressure test results of Black cotton soil with different combinations of Quarry dust:

\begin{tabular}{|l|l|}
\hline Sample & $\begin{array}{l}\text { swell } \\
\text { pressure } \\
\mathrm{kg} / \mathrm{cm}^{2}\end{array}$ \\
\hline Black cotton $+0 \%$ quarry dust & 0.428 \\
\hline Black cotton $+10 \%$ quarry dust & 0.254 \\
\hline Black cotton $+20 \%$ quarry dust & 0.219 \\
\hline Black cotton $+30 \%$ quarry dust & 0.112 \\
\hline Black cotton $+40 \%$ quarry dust & 0.0509 \\
\hline
\end{tabular}

\section{RESULTS AND DISCUSSION}

Results of black cotton soil are compared with different percentages of Quarry dust

\subsection{Effect of the Quarry Dust on the California Bearing Ratio (Table III)}

The California bearing ratio test results obtained from tests conducted on black cotton with replacement of quarry dust.

With the addition of $10 \%$ of quarry dust by weight the C.B.R. value for plain soil is increased from $6.723 \%$ to $7.12 \%$.

With the addition of $20 \%$ of quarry dust by weight the C.B.R. value for plain soil is increased from $6.72 \%$ to $11.94 \%$.

With the addition of $30 \%$ of quarry dust by weight the C.B.R. value for plain soil is increased from $6.72 \%$ to $12.02 \%$.

With the addition of $40 \%$ of quarry dust by weight the C.B.R. value for plain soil is increased from $6.72 \%$ to $12.6 \%$.

\subsection{Effect of the Quarry Dust on the Swell Pressure}

\section{(Table III)}

The swell results obtained from tests conducted on black cotton soil with replacement of quarry dust.

With the addition of $10 \%$ of quarry dust by weight the C.B.R. value for plain soil the swell pressure decreases from $0.482 \mathrm{~kg} / \mathrm{cm}^{2}$ to $0.254 \mathrm{~kg} / \mathrm{cm}^{2}$

With the addition of $20 \%$ of quarry dust by weight the C.B.R. value for plain soil the swell pressure decreases from $0.482 \mathrm{~kg} / \mathrm{cm}^{2}$ to $0.219 \mathrm{~kg} / \mathrm{cm}^{2}$

With the addition of $30 \%$ of quarry dust by weight the C.B.R. value for plain soil the swell pressure decreases from $0.482 \mathrm{~kg} / \mathrm{cm}^{2}$ to $0.112 \mathrm{~kg} / \mathrm{cm}^{2}$
With the addition of $410 \%$ of quarry dust by weight the C.B.R. value for plain soil the swell pressure decreases from $0.482 \mathrm{~kg} / \mathrm{cm}^{2}$ to $0.0509 \mathrm{~kg} / \mathrm{cm}^{2}$

\section{CONCLUSION}

From the above discussion it is concluded that with the addition of $40 \%$ quarry dust for black cotton soil the C.B.R value is increased by $87.5 \%$.

With the addition of $40 \%$ of quarry dust for black cotton soil the swell pressure decreases by $88 \%$

\section{REFERENCES}

[1]. V Rama Susheel Kumar, J Vikranth. Application of Coconut Coir and Fly ash in Sub grade strengthening. The International Journal Of Engineering And Science. Vol 3, Issue 12, 2014.

[2]. Onyelowe Ken C, Okafor F. O, Nwachukwu D. G. Geophysical use of quarry dust (as admixture) as applied to soil stabilization and modification. ARPN Journal of Earth Sciences. Vol 1, No. 1, 2012.

[3]. Ms. Arpitha and V.Patel. Study of geotechnical properties of black cotton soil contaminated by castor oil and its stabilization by sawdust. National Conference on Recent Trends in Engineering \& Technology. 2011.

[4]. T.S. Ijimdiya, A.L. Ashimiyu, D.K. Abubakar. Stabilization of Black Cotton Soil Using

Groundnut Shell Ash. EJGE, Vol 17, 2012.

[5]. Anu Paul, Anumol V S, Fathima Moideen, Jiksymol K Jose, Alka Abraham. Studies on Improvement of Clayey Soil Using Egg Shell Powder and Quarry Dust. International Journal of Engineering Research and Applications. Vol 4, Issue 4, 2014.

[6]. Udayashankar D.Hakari, S.C.Puranik. Stabilisation of Black Cotton Soils Using Fly Ash, HubballiDharwad Municipal Corporation Area, Karnataka. Global Journal of researches in engineering Civil And Structural engineering. Volume 12, Issue 2, 2012.

[7]. Purushotham, Sitaram Nayak. Studies on utilization of quarry dust to improve the geotechnical properties of lithomarge clay. International Journal of Advanced Structures and Geotechnical Engineering. Vol 3, No 1, 2014.

[8]. Najia Nouf, Sureka Naagesh. Effect of RBI-81 on properties of black cotton soil. International Journal of Recent Development in Engineering and Technology, 2014. [9]. Akanbi, D.O, Job, F.O. Suitability of Black Cotton (Clay) Soil Stabilized with Cement And Quarry Dust for Road Bases and Foundations. EJGE. Vol 19, 2014.

[10]. H. P. Singh, M. Bagra. Improvement in CBR value of soil reinforced with jute fiber. International Journal of Innovative Research in Science, Engineering and Technology. Vol. 2, Issue 8, 2013. 